\title{
Temporal and spatial prediction of retailer growth
}

\author{
Bertha Maya Sopha ${ }^{1, *}$, Fredrika Makasenda ${ }^{1}$, and Anna Maria Sri Asih ${ }^{1}$ \\ Industrial Engineering Programme, Department of Mechanical and Industrial Engineering, \\ Universitas Gadjah Mada, 55281 Yogyakarta, Indonesia
}

\begin{abstract}
Retailers have significantly affected good distribution and eventually transportation cost, traffic congestion, and pollution. Understanding spatial development of retailers is therefore of importance in planning logistics particularly in urban areas. The present research aims at predicting retailer growth both temporally and spatially. Both time-series forecasting using Holt's model and spatial forecasting using ArcGIS were conducted. Results indicate that the existing retailers of Yogyakarta city have already exceeded the minimum requirement of retailers following the Indonesian National Standard, whereas other four districts have need of more retailers. Furthermore, it appears that the connectivity to the road network appears to be the important parameter in determining future location of retailers, contrasting traditional perspective of clustered location at central business area.
\end{abstract}

\section{Introduction}

Retail industry is an industrial sector that sells value-added products and services to meet personal, family, group or end-user needs. Most products sold are the fulfilment of household needs including nine staples. Indonesia is among countries in the world with positive population and economic growth. The growth is eventually corresponding to the significant growth of retail industry in Indonesia. The retail industry in Indonesia contributes substantially to Gross Domestic Product (GDP) and also absorbs large amounts of manpower. As a developing country, the growth rate of Indonesia's retail industry is influenced by the power of people's purchasing power, population growth, and also the people's need for the fulfilment of consumption products. It was recorded that annual growth of retailers in Indonesia is in the range of 10\%-15\% [1]. Furthermore, average growth of modern retailers is almost twice higher than that of traditional retailers.

Retailers have played an important role in goods distribution. Through retailers, a product can meet directly with its users. It is therefore the location of retailers appears to be the most significant factor in establishing effective and efficient operations because consumers tends to buy goods from nearby stores. From company perspective, retailer site selection is critical because it significantly influences distribution cost. The companies

\footnotetext{
*Corresponding author: bertha_sopha@ugm.ac.id
} 
determines the location of retailers in such a way to maximize services to customers' demand while minimizing distribution cost.

From government perspective, number and location of retailers is of significance because it contributes to traffic congestion and, subsequently, pollution. Through Indonesian National Standard No. 03-1733-2004 [2], the government has regulated that the distance between retails should be at least 500 meters, and one retail must be able to reach consumers within a radius of 2000 meter. Further, the standard also regulates that one type of shop/retailer can support 6000 people, while a shopping centre can support 30,000 people. To meet dynamic customer demand and to achieve customer satisfaction, the location and quantity of retailers should be managed toward successful operation of logistics. It is therefore necessary to understand the pattern growth of retailers so that distribution operations can be properly designed. It becomes particularly important when the government has planned to establish urban distribution centre to improve efficient logistics, as well as to reduce traffic congestion, and negative environmental impact.

This present paper aims at predicting both temporal and spatial growth of retailers. Special Region of Yogyakarta was selected as a studied case because the region has experienced dramatic increase of modern retailer growth since 2009. In addition, the local government has also planned the establishment of urban distribution centre in the province to support efficient logistics operation and to reduce traffic congestion in urban areas.

Spatial aspect is predominantly important because designing appropriate logistics operation needs not only the number of retailers but also spatial distribution of retailers. On the other hand, most literatures focus on predicting the growth of retailers with respect to the number of retailers without addressing the spatial distribution of the potential retailers. Studies exploring spatial aspect of retailers are rare, which makes the spatial forecasting of retailers are the novel contribution of the present paper. The study applies spatial analysis using Geographical Information System (GIS) to predict spatial distribution of prospective retailers in the province. The spatial information of the retailers is useful the government to further examine the alternative locations of the urban distribution centre.

The rest of the paper will be structured as follows. This section has discussed the research background as well as the research contribution. The next section introduces determinant factors of retail location. Section Three presents the methodology, followed by results and discussion in Section Four. The last section concludes the research.

\section{Literature Review}

This section discusses factors influencing the location of retailers which are then used as a literature background for further analysis. There are two mainstream approaches to predict retailers' location. The first approach, known as centralized retail location envisages the location of retailers have a tendency to be located in the centre of the city. On the contrary, the second approach holds that the development of modern retail follows the decentralization pattern of the region. Factors influencing the decentralization pattern include changes in demand, changes in retail organization, land-use, labour conditions, technological changes and planning policies, and trading activities such as distribution and exchange of goods. For instance, retailers' location is selected to enable future expansion city centre may not be appropriate due to limited available spaces.

Following [3], four factors to be considered when selecting new store location are traffic, frontage, expansion possibility, and population threshold. Heavy traffic volume, traffic density and congestion is not preferable due to safety reason. It could be a barrier for firemen, police services, or ambulances. Wide frontage and secure access to in and out of the site are required for loading and unloading goods. Available large space enough for future business expansion is also indispensable. Population threshold referring to the 
minimum demand level is required to support the sustained operation of retailers. Threshold is closely related to the nature and frequency of demand for goods and services.

Furthermore, determining location of retailers is also based on goods reach, which is corresponding to the distance that must be taken by customers to buy goods/services at a certain price. Consumers will incur additional costs as a combination of the amount of money spent, time and effort. Each customer normally selects an easy-to-reach location with minimal travel to visit the retailer. For that reason, the selected location requires a high level of accessibility [4].

Last but not least, retailers' location should also comply with Indonesian National Standards No. 03-1733-2004 [2] and government regulation No. 112 Year 2007 [5] which states that retailers can be located on road network system in an urban/municipal areas or trade/business areas.

Based on the aforementioned factors, the study applies accessibility, land availability, population threshold, standards and regulations, as restraining factors in predicting potential retailers.

\section{Methodology}

This section presents the specific methodology used in the study. As Special Region of Yogyakarta consists of four districts and one city, i.e., Kulonprogo district, Bantul district, Gunung Kidul district, Sleman district, and Yogyakarta city, with different sociodemographic characteristics, the unit of analysis of the study is district/city. The methodology consists of two main steps: time-series forecasting of retailers based on population dynamics and spatial forecasting of potential retailer locations.

The first step of time-series forecasting was conducted following the standard procedure of forecasting according to [6]. Historical population data of 1993-2015 was used to predict the population for the next 10 years (until 2025). Mean Absolute Percentage Error, Mean Absolute Deviation and Mean Squared Deviation were used to evaluate the accuracy of prediction. Using the Indonesian National Standard No. 03-1733-2004 [2], the number of required retailers until 2025 was then estimated based on the forecasted population.

The second step relates to the spatial prediction of retailer locations. Once the number of required retailers for each district was evaluated, the spatial distribution of the retailers for each district was estimated using ArcGIS. The second step entailed two sub-steps; i.e., potential location assessment, and retailer location generation. With respect to potential location assessment, various constraints, i.e., land-use constraint, accessibility, land availability and required minimum distance between retailers were considered. According to the government regulation No. 112 Year 2007 [5], retailers should be located on either urban/municipal areas or trade/business areas. Following, Presidential Regulation No.112 Year 2007, the minimum areas for shopping facilities should be between 50-400 squaremeter [5]. These areas were then additionally constrained with land-availability for expansion and accessibility. This research therefore used the connection to road network (local road, collector road, and arterial road) as a parameter. Moreover, following Indonesian National Standard No. 03-1733-2004 which determines that the required minimum distance between retailers (traditional markets or existing modern retailers) are 500 meters [2], buffer analysis was conducted to further restraint the potential areas. The aforementioned description was then formulated into an analytical model which was an optimization model as the following.

Objective function:

Maximize $F=\sum_{i=1}^{n}\left(L_{i} x_{i}+J_{i} x_{i}+D_{i} x_{i}\right)$ 
Constraint:

$$
\sum_{i=1}^{n} w_{i} x_{i} \leq K
$$

where,

$\mathrm{F}=$ the fitness of predicted locations of retailers

$\mathrm{Xi}=$ predicted location (binary: 0 or 1 ), $\forall \mathrm{i}=1, \ldots, \mathrm{n}$

$\mathrm{Li}=$ land-use (binary: 0 or 1$), \forall \mathrm{i}=1, \ldots, \mathrm{n}$

$\mathrm{Ji}=$ connection to road network (binary: 0 or 1 ), $\forall \mathrm{i}=1, \ldots, \mathrm{n}$

$\mathrm{Di}=$ land expansion possibility (binary: 0 or 1 ), $\forall \mathrm{i}=1, \ldots, \mathrm{n}$

$\mathrm{K}=$ the required minimum distance between retailers of 500 meters

$\mathrm{Wi}=$ distance between the predicted location with nearby retailers (meter)

The initial predicted location was generated based on spatial statistical analysis, i.e., Kernel Density Estimation and Average Nearest Neighbour which was based on spatial pattern of existing retailer locations. The optimization model was then solved using greedy algorithm within ArcGIS to obtain the feasible potential retailer locations.

\section{Results and Discussion}

This section is divided into two parts following the methodological stages, i.e., temporal forecasting and spatial forecasting of future potential retailers. Results of spatial growth of retailers are presented for each district.

\subsection{Time-Series Forecasting of Retailers}

Time-series forecasting using historical data in the period of 1993-2015 was carried out to forecast the population until the year of 2025. Based on autocorrelation analysis, four forecasting models, i.e., linear trend, quadratic trend, exponential growth trend, and Holt's model were examined. It was found that Holt's model gave the smallest prediction error. Using the standard No. 03-1733-2004 [2], Table 1 presents the required retailers until the year of 2025. It appears that Yogyakarta city has already sufficient retailers, so that spatial prediction of retailers was conducted for all districts but Yogyakarta city. Consequently, due to the strong increase of modern retailers in Yogyakarta city, the city major has issued regulation No. 79 Year 2010 to limit minimarket to protect traditional markets [7].

Table 1. Forecasted Retailers in 2025

\begin{tabular}{|l|r|r|r|r|r|r|}
\hline \multicolumn{1}{|c|}{ District } & $\begin{array}{c}\text { Estimated } \\
\text { Population }\end{array}$ & \multicolumn{1}{c|}{$\begin{array}{c}\text { Area } \\
\mathbf{( k m}^{\mathbf{2}} \mathbf{n}\end{array}$} & \multicolumn{1}{c|}{$\begin{array}{c}\text { Existing } \\
\text { Shops }\end{array}$} & $\begin{array}{c}\text { Existing } \\
\text { Shopping } \\
\text { Centers }\end{array}$ & $\begin{array}{c}\text { Required } \\
\text { Shops* }\end{array}$ & $\begin{array}{c}\text { Required } \\
\text { Shopping } \\
\text { Centers* }\end{array}$ \\
\hline Bantul & $1,290,856$ & 507 & 75 & 34 & 141 & 9 \\
\hline Gunung Kidul & 919,322 & 586 & 37 & 35 & 117 & -5 \\
\hline Kulon Progo & 418,894 & 1,485 & 54 & 27 & 16 & -13 \\
\hline Sleman & $1,591,601$ & 575 & 361 & 51 & -96 & 3 \\
\hline Yogyakarta & 493,895 & 33 & 197 & 31 & -115 & -15 \\
\hline
\end{tabular}

Note: *minus indicates the existing retailers are exceeding the minimum required retailers according to the Indonesian National Standard No. 03-1733-2004 [2] 


\subsection{Spatial Prediction of Retailers}

Figure 1 shows locations of existing retailers and results of buffer analysis. Buffer analysis shows population areas which have not yet reached by existing retailers. Bantul and Gunung Kidul are the two districts with far from sufficient number of retailers. On the contrary, all areas in Yogyakarta city have been covered by retailers, and the existing retailers have exceeded the standard of minimum retailers.

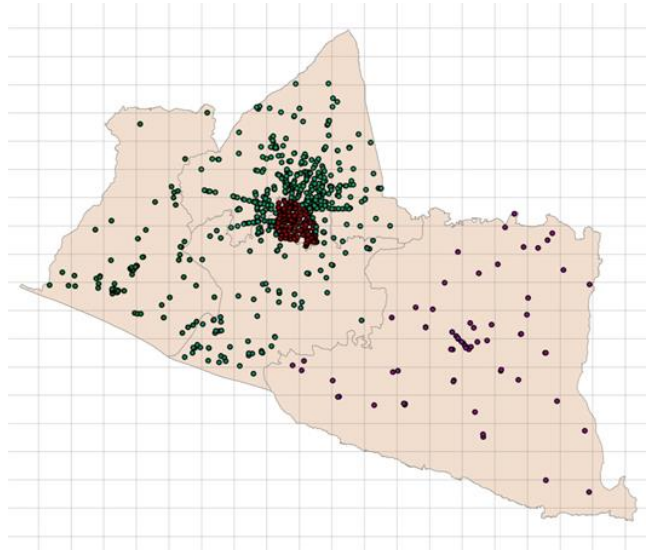

(A) Locations of existing retailers

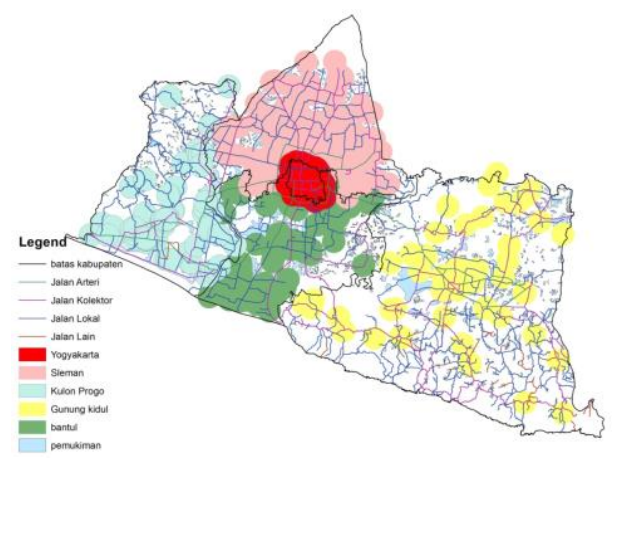

(B) Buffer analysis

Fig. 1. Buffer Analysis

Figure 2 shows results of spatial prediction of retailer growth until 2025 for each district in the Special Region of Yogyakarta Province, except Yogyakarta city. It appears that the predicted retailer locations are scattered, not clustered in a certain area. Apparently, the distribution of predicted retailer location is not dependent on the location of central business area, rather following road network. The connectivity to road network seems to be the most influenced factor in determining retailer location. It is indicated that the predicted retailers tends to be built in areas which is connected to the road network, contrasting the traditional perspective stating that retailers tends to locate at central business area.

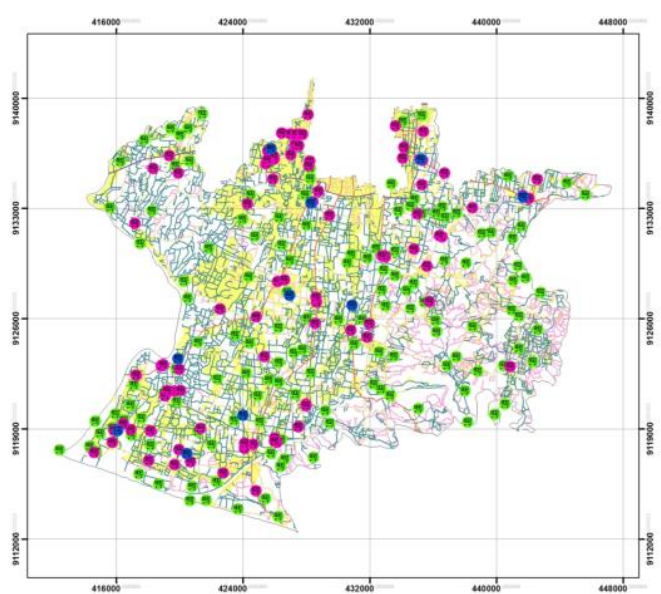

A.Spatial Prediction of Retailers in Bantul District

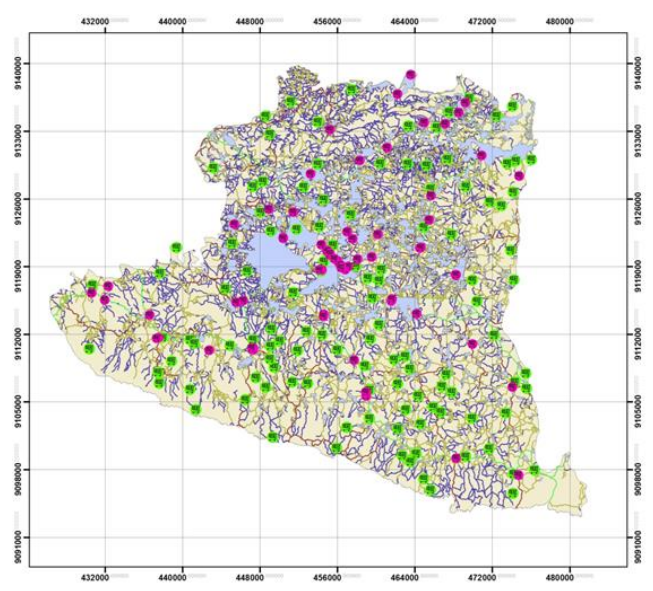

B. Spatial Prediction of Retailers in Gunung Kidul District 


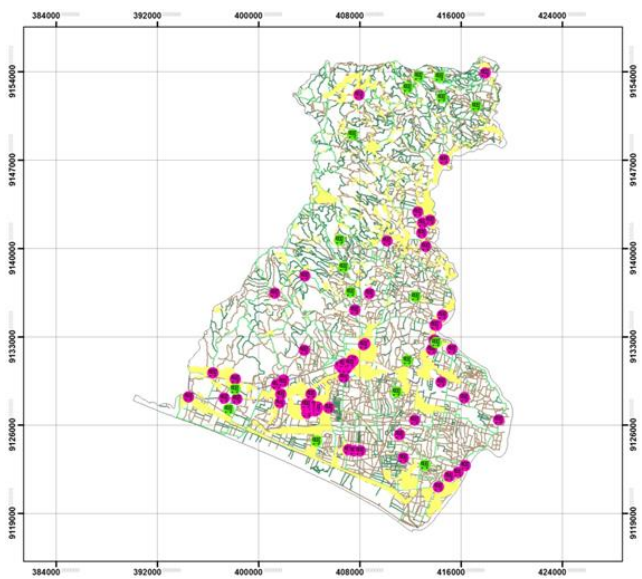

C. Spatial Prediction of Retailers in Kulon Progo District

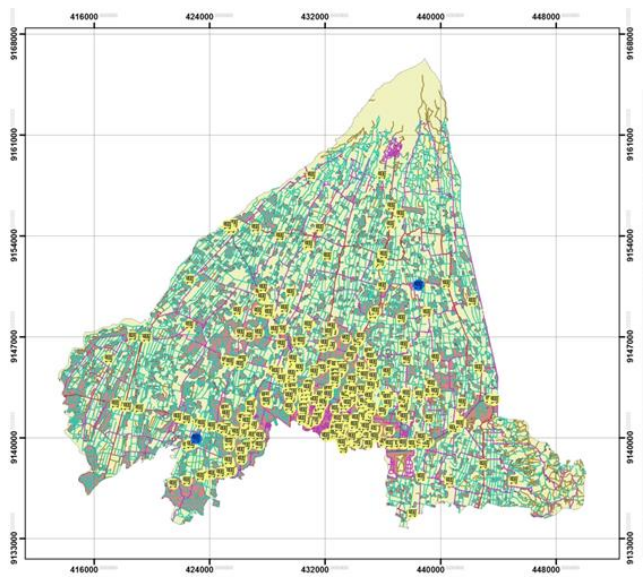

D. Spatial Prediction of Retailers in Sleman District

Fig. 2. Spatial Prediction of Retailers Growth (Note: violet/yellow dot represents existing retailers, green dots represents predicted shops, blue dots represents predicted shopping centres)

\section{Conclusion}

Due to the growing importance of retailer locations in managing good distribution and logistics of urban areas, the present research contributes the temporal and spatial prediction of retailer growth. Special Regional of Yogyakarta Province was taken as a studied case. Two-stage methodological approach, i.e., time-series forecasting using Holt's model and spatial forecasting using spatial statistical analysis in ArcGIS were carried out to predict the number and the location of potential retailers respectively. Results indicate that Bantul, Kulon Progo, Gunung Kidul, and Sleman districts are still in need of retailers. The predicted location of retailers tends to be along the road network. It may shift the traditional view which holds that retailers are clustered at central business area to a decentralization pattern that retailers are more distributed following road network. Future research could investigate other empirical cases to generalize the findings of the present research.

\section{References}

1. Asosiasi Perusahaan Ritel Indonesia (Aprindo). Pertumbuhan Bisnis Ritel di Indonesia. http://www.aprindo.org/, accessed on January 2013.

2. Indonesian National Standard SNI 03-1733-2004. http://sispk.bsn.go.id/SNI/DetailSNI/6694, accessed on June 2017.

3. D. Benoit, G. P. Clarke. Assessing GIS for retail location planning. J. Retailing \& Cons. Serv. 4, 4, 239-258 (1997).

4. M. Yeates, B. Garner. The North American City, New York, Harper and Row Publishers (1980).

5. Peraturan Presiden No. 112 Tahun 2007. http://www.bphn.go.id/data/documents/07pr112.pdf, accessed on August 2017.

6. J. E. Hanke, D. Wichern. Business Forecasting. Pearson (2008).

7. Yogyakarta Major Regulation No. 79 Year 2010. http://hukum.jogjakota.go.id/data/10079.pdf, accessed on February 2018. 